\title{
Grzegorz Smyk
}

Maria Curie-Skłodowska University in Lublin

ORCID: 0000-0003-0143-4233

grzegorz.smyk@poczta.umcs.lublin.pl

\section{The Position and Role of So-called "Mixed Offices" in the Governorate Administration of the Kingdom of Poland after the January Uprising}

\author{
Miejsce i rola tzw. urzędów mieszanych w administracji gubernialnej \\ Królestwa Polskiego po powstaniu styczniowym
}

\section{SUMMARY}

The Russian model of supervision and control of administration was introduced in the Kingdom of Poland concurrently with the reorganisation of the governorate and district administration after the January Uprising. The supervisory functions were taken over by the newly established bodies of the governorate and district administration of individual sectors of ministerial administration, for which the ministers residing in St. Petersburg were the final decisive body. On the other hand, the abolition of the Council of State of the Kingdom of Poland in 1867 entailed the final liquidation of the administrative justice system based on the French model, which had operated on these lands since the times of the Duchy of Warsaw. Its tasks were taken over by so-called "mixed offices" which filled the resulting gap only partially. Unlike administrative courts, these offices formed an integral part of the governorate administration, and their clerical staff as well as the bureaucratic method of operation compromised their judicial independence. Moreover, the procedure for dispute resolution in these offices had the character of an intra-administrative procedure which did not employ the concept of a party, and its discretionary course excluded the possibility of applying the principles of adversarial process, openness to the public or dispositiveness. The peculiarity of "mixed offices" in the Kingdom of Poland, resulting solely from political reasons, was the reduction of their staffing only to the bureaucratic element and full subordination of their substantive and formal side of the proceedings to the governorate authorities. As a result, the judicial activity of "mixed offices" in administrative matters in the Kingdom of Poland was much more dependent on the current policies of the tsarist authorities represented and supervised directly by the governors than in the interior governorates of the Empire. The combination of these factors with the discretionary rules of intra-ministerial proceedings applied in these offices deprived inhabitants of the Kingdom of Poland of a guarantee of impartial defence of their rights and interests in disputes with the administration that was foreign and distrustful to them.

Keywords: administration; administrative judiciary; Kingdom of Poland; Russian Empire 


\section{INTRODUCTION}

One of characteristic features of modern European countries in the $19^{\text {th }}$ and $20^{\text {th }}$ centuries was the formation of institutional instruments for internal and external review of public administration, which guaranteed both the principle of legality of administrative activity and the direct or indirect protection of individual civil rights in the field of public law. The distinction between these two functions occurred concurrently with the formation and practical implementation of the constitutional rule of law, with particular emphasis on the compliance of the administration with the legal order and the ability to defend the rights and interests of individuals via the administrative judiciary. As a consequence, at least since the second half of the $19^{\text {th }}$ century, supervision had been understood as an upper-instance review of administrative activities of lower organs by superior authorities, which involved the possibility of direct interference by superior authorities in the decision-making processes of the subordinate bodies, including the use of sovereign means (so-called managerial supervision). On the other hand, the concept of review was interpreted narrowly as judicial settlement of administrative disputes ${ }^{1}$. Therefore, the concept of supervision was identified, as it is also today, with the concept of internal review while the concept of review - with the administrative judiciary, i.e. one of the forms of external review of administrative activities ${ }^{2}$. The natural consequence of the distinction between the supervisory and review functions of public administration was the emergence of the organisationally separate administrative judiciary system, independent of the structures of the so-called "active administration". In Europe,

\footnotetext{
H. Izdebski, Historia administracji, Warszawa 1997, pp. 116-119; W. Witkowski, Historia administracji w Polsce 1764-1989, Warszawa 2007, pp. 47-48.

2 Nowadays, the term "review" is used to define the functions of an administrative body involving solely the verification of activities of other organisational units, without the permanent possibility of interfering in the activities of the entities under review, by issuing orders or instructions. On the other hand, the term "supervision" is used most often to depict a situation in which the supervisory authority is equipped with sovereign measures to influence the conduct of the supervised bodies, which is understood as the so-called managerial supervision. The term "supervision" points to the sovereign nature of its implementation, while "review", by its definition, is not intended to apply measures of this nature. Thus, the essence of review activity is to observe certain processes, analyse their nature and present these observations to the authorities which lead the public administration. The reviewing body is not directly responsible for the activities of the reviewed body. However, the supervisory body not only observes and assesses, but also co-manages and is responsible for the results of the organisation activities of the bodies that are subject to supervision. See Prawo administracyjne, red. M. Wierzbowski, Warszawa 2000, p. 103; Z. Duniewska, B. Jaworska-Dębska, R. Michalska-Badziak, E. Olejniczak-Szałowska, M. Stahl, Prawo administracyjne. Pojęcia, instytucje, zasady w teorii i orzecznictwie, Warszawa 2000, pp. 369-373; J. Starościak, Prawo administracyjne, Warszawa 1978, p. 349; J. Ochendowski, Prawo administracyjne. Część ogólna, Toruń 2006, pp. 414-423; J. Boć, Kontrola prawna administracji, [in:] Prawo administracyjne, red. J. Boć, Wrocław 1997, pp. 329-335.
} 
the model solutions of administrative justice so understood were first introduced in France, Austria and the UK. In this context, the situation was completely different both in the Russian Empire and in the Kingdom of Poland (the so-called Congress Poland) which shared the systemic features of the former in the period after the January Uprising of 1863-1864.

The first, and initially the only, body for the review and supervision of the public administration of the Russian state was the Governing Senate, which performed these functions under both administrative and judicial procedures ${ }^{3}$. In the second half of the $19^{\text {th }}$ century, the Senate's powers for the review of administration became the beginning of the Russian administrative judiciary. It was based on the provision of Article 47 of the Fundamental Laws of the Russian Empire in their edition of 1835, according to which, all state organs, including administrative authorities, were supposed to act on the basis of applicable law ${ }^{4}$. An infringement of law by an administrative body authorized private or legal entities to file a complaint against the decisions violating their rights. However, the review of administration in such cases boiled down only to the examination of legalism of the decisions taken, and not to the assessment of their effects ${ }^{5}$. The wide range of administrative decisions, against which the interested entities were entitled to appeal to the relevant Senate departments, had caused that beginning from the second half of the $19^{\text {th }}$ century, special bodies were established within the government administration, competent for specific areas of the administrative governance, and even for individual subjects of administrative activity of the state. In principle, they were supposed to decide in the first instance on appeals about certain decisions of state administration bodies, apart from the decisions of ministers and other central authorities. These included: Governorate Offices for Peasant Affairs (established in 1861 and then reorganized in 1889), Governorate Offices for Municipal Affairs (since 1870), Governorate Offices for Land Affairs (from 1890) - appointed for the control of the activity of rural, urban and land self-government in the inner governorates of the Empire, and then:

3 "The Governing Senate is the supreme judicial, administrative and executive body to which all the authorities and offices of the Empire are reporting, apart from the higher administrative authorities and those offices which, under separate laws, have been excluded from this subordination" - Decree of 2 / 13 March 1711 on the authority and responsibility of the Governing Senate, "Polnoe Sobraniye Zakonov Rossiyskoy Imperii" (hereinafter referred to as PSZRI) 1830, No. 2328, p. 654; Uchrezhdeniye Pravitelstvuyushchago Senata, "Svod Zakonov Rossiyskoy Imperii" (hereinafter referred to as the "Svod Zakonov") 1892, Vol. I, part II, book IV, p. 1, Article 1.

4 Svod Osnovnykh Gosudarstvennykh Zakonov Rossiyskoy Imperii, izdaniye 1835, "Svod Zakonov"1835, Vol. I, part I, p. 18, Article 47.

5 V.V. Ivanowsky, Uchebnik administrativnogo prava, Kazan 1908, pp. 164-167; I.T. Tarasov, Kratky ocherk nauki administrativnogo prava, "Vriemennik Demidovskogo Juridicheskogo Litseya", Yaroslavl 1888, p. 47; A.I. Elistratov, Osnovnye nachala administrativnogo prava, Moskva 1914, pp. 258-269; N.M. Korkunov, Russkoe gosudarstvennoe pravo, Vol. 2, Sankt Peterburg 1908, pp. 499-508. 
Governorate Offices for Military Duties (from 1874), Provincial Offices for Factory Affairs (from 1886), transformed in 1899 into the Governorate Offices for Factory and Mining Affairs, and Governorate Offices for the House Rental Tax (since 1893), and the Governorate Offices for the Industrial Tax (since 1898) - appointed as an instance of appeal against the decisions of enlistment offices and tax authorities, i.e. revenue offices. The last established authorities were the Governorate Offices for Associations established in 1906, which dealt with the matters of registration and auditing of activities of associations and unions. Due to the peculiar composition and scope of responsibilities, these offices used to be referred to in the literature on the subject as "mixed offices" (smeshannya prisutstviya) ${ }^{6}$. They were always composed of the governor, the deputy governor, the prosecutor of the regional court and the head of the governorate revenue office, and representatives of the self-government, gentry and entrepreneurs, and the payers of certain types of taxes, either elected in general election or appointed by the governorate administrative authorities, with the bureaucratic element always prevailing in such offices. Beside considering appeals, they were also responsible for selected supervisory or even decision-making issues, in which they were fully dependent on the governorate's general administration authorities, i.e. on the governors. As a result, the administrative justice system at the lowest instance was not separated from the general administration sector but, while being integrated into its structures, was considered, from the formal point of view, a special way of intra-administrative proceeding. On the other hand, complaints against officials for the redress of damage caused by their negligence or abuse of power were subject to recognition by common courts. Their scope of jurisdiction depended on the rank of the official, and the adjudicating panel was composed of, along professional judges, two representatives of the relevant administration sector with a decisive voice ${ }^{7}$. Thus, also in such cases, the judiciary and administration intertwined resulting in a quasi-judicial character of the review of administrative activity.

Initially, the appellate instance in contentious cases settled by the administration was the $1^{\text {st }}$ Department of the Senate (the so-called "Administrative Department"), from which the $2^{\text {nd }}$ Department (the so-called "Peasantry Department") was separated in 1884, responsible for matters resulting from the implementation of enfranchisement reforms in the Russian Empire and the Kingdom of Poland. These departments, together with the Heraldic Department established in 1848, were unofficially called "Administrative Departments of the Government Senate" (Administratsionnye Departamenty Pravitelstvuyushchago Senata). They only consisted of officials appointed by the Emperor, and they had to obtain a preliminary consent from the competent

6 S.A. Korf, Administratiwnaja justicja w Rossiji, Vol. 1, Sankt Peterburg 1910, pp. 212-283; A.I. Elistratov, op. cit., pp. 269-285.

7 S.A. Korf, op. cit., Vol. 1, pp. 212-283; idem, Administratiwnaja justicja w Rossiji, Vol. 2, Sankt Peterburg 1910, p. 277; A.I. Elistratov, op. cit., pp. 269-285. 
minister in order to recognize administrative cases, which clearly ruled out their independence and separation from the administration. Within the internal structure of the Senate, these departments were separate and independent organisational units (since the middle of the $18^{\text {th }}$ century, the Senate did not act as a uniform body), and their decision-making powers were equal. Their responsibilities in the field of administrative judiciary included the hearing, in the second and sometimes even in the third instance, of appeals against decisions of "mixed offices" and other administrative bodies, as well as complaints against decisions of ministers. Decisions taken in the Administrative Departments of the Senate were, in principle, final. However, at the request of the public prosecutor's office or the ministers concerned, and even on the order of the Emperor following a request from an individual, a case concluded with a final decision of the department could be remanded for reconsideration by the joint panel of the $1^{\text {st }}$ and $2^{\text {nd }}$ Departments and Heraldic Department acting under the common name: "1st General Assembly of Departments of the Governing Senate" (I Obshchee Sobraniye Departamentov Pravitelstvuiushchago Senata). Its decision was final and did not require the Emperor's approval ${ }^{8}$.

The Russian model of supervision and control of administration was introduced in the Kingdom of Poland concurrently with the reorganisation of the governorate and district administration after the January Uprising. The supervisory functions were taken over by the newly established bodies of the governorate and district administration of individual sectors of ministerial administration, for which the ministers residing in St. Petersburg were the final decisive body. On the other hand, the abolition of the Council of State of the Kingdom of Poland in 1867 entailed the final liquidation of the administrative justice system based on the French model, which had operated on these lands since the times of the Duchy of Warsaw. Its tasks were taken over by the "mixed offices" which filled the resulting gap only partially. In the Kingdom of Poland there were no Governorate Offices for Municipal and Land Affairs, as the tsarist authorities had not established self-government institutions of this level in the Kingdom?

\section{GOVERNORATE OFFICES FOR PEASANTS'AFFAIRS}

The first "mixed offices" introduced by the tsarist authorities in the Kingdom of Poland were the Governorate Offices for Peasant Affairs, established by the decree of 18-30 November 1870, which replaced the previously operating Peasantry

\footnotetext{
8 N.M. Korkunov, op. cit., pp. 530-535; A.I. Elistratov, op. cit., pp. 259-260; S.A. Korf, op. cit., Vol. 1, pp. 347-354.

9 K. Grzybowski, Historia państwa i prawa Polski, t. 4: Od uwłaszczenia do odrodzenia Państwa, Warszawa 1982, pp. 95-96; A. Mogilnicki, Sady administracyjne, Warszawa 1900, pp. 169-171.
} 
Commissions, established to implement the 1864 enfranchisement decrees ${ }^{10}$. These offices followed the model of similar institutions existing since 1861 in interior governorates of the Empire, but due to different legal regulations and the nature of enfranchisement reforms in the Kingdom, they differed from them both in terms of internal organisation and responsibilities conferred on them ${ }^{11}$. Governorate Offices for Peasant Affairs in the Kingdom of Poland consisted of: the Governor as chairman, the Deputy Governor as deputy chairman, the head of the revenue office in the governorate, one permanent member (nepremenny chlen), appointed by the Emperor at the request of the Minister of the Interior from among officials of the peasantry administration, and district peasantry commissioners. Each office had a chancellery led by the permanent member, composed of the secretary, geometers and office staff. The decisions in the office were taken collectively, and they required for their validity a quorum of at least three persons, including the permanent member of the office and one district peasantry commissioner, and where the permanent member was absent - two commissioners. Meetings were convened and chaired by the governor or the deputy governor in the absence of the former ${ }^{12}$.

The responsibilities of the Governorate Office for Peasant Affairs covered matters dealt with by the liquidated Peasantry Commissions, i.e.: 1. Checking and correcting the liquidation and enfranchisement tables presented by manor lords and putting them into execution, 2. Certification of voluntary agreements between manor lords and peasants for the repeal or modification of the use of land easement, swapping of land and arable areas, transfer of colony settlements, etc., 3. Resolution of disputes between the manor and peasants regarding land and easements, and complaints brought by both parties on that subject, 4 . Recognition of requests for

10 Decree of 18 / 30 November 1870 on the establishment at the Ministry of Internal Affairs of the Interim Commission for Peasant Affairs in the Governorates of the Kingdom of Poland and renaming the Peasantry Commissions in the Kingdom of Poland into governorate offices for peasant affairs, "Journal of Laws", Vol. 71, pp. 59-67, Articles 1-6; C. Ochryzko-Włodarska, Organizacja władz włościańskich w Królestwie Polskim i ich pozostatość aktowa, Warszawa 1973, pp. 29-32.

11 This concerns the Governorate and District Offices for Peasant Affairs, as well as the Main Committee for the Organisation of Peasantry, established in 1861 for the implementation of rural reforms in the Empire. See Decree of 19 February / 2 March 1861 - Provisions on the organisation of governorate and district offices for peasant affairs, PSZRI 1861, No. 36660, pp. 217-218, Articles 125-132.

12 "In each governorate, in place of the Peasantry Commission, a Governorate Office for Peasants Affairs shall be established under the Governor's presidency and composed of the Deputy Governor who acts as chairman in the absence of the Governor, and the Permanent Member, the head of the Revenue Office and district commissioners. For resolutions to be valid, the Governorate Office shall consist of the Chairman or his deputy and at least two members, including the Permanent Member and one of the district commissioners, and in the absence of the Permanent Member - of two Commissioners. [...] The members of the Governorate Office shall be appointed and dismissed upon a request of the Minister of the Interior under the Highest Permit" - Decree of 18 / 30 November 1870 on the establishment at the Ministry of Interior of an Interim Commission for Peasant Affairs in Governorates of the Kingdom of Poland, pp. 59-61, Article 1 item 2. 
compulsory separation of manor land from peasants' land, liquidation of easements and division of rural communities, 5. Distribution and taking of abandoned (vacant) farms, 6. Recognition of complaints about the activities of District Commissioners, 7. Explaining the importance of the decree on enfranchisement and preventing the spread of its false interpretations, 8 . Supervision of the election of commune authorities, distribution of land tax and commune duties, and the approval of commune meeting resolutions, approved by the District Commissioner, on the division of commune's land, 9. Supervision of the measurement of rural land, 10. Recognition of requests from competent authorities to modify the boundaries of districts of municipal courts, designation of their sites and the time limits for the appointment of judges, 11. Granting authorisations for the establishment or closure of peasants' credit unions, 12. Supervision of the procedure of alienation, lease, letting or pledge of settlements and the peasants' land and countering their fragmentation ${ }^{13}$. Moreover, in 1870, an additional obligation was imposed on these offices, to:

[...] consider and decide on: a. complaints on village mayors' orders on the custody of minors and on decisions of family councils, b. complaints against resolutions of commune meetings concerning the distribution of the hearth tax and land tax, c. cases of cessation of rent obligations ${ }^{14}$.

For their settlement, a Special Office (Osoboe Prisutstvie) was separated from the Governorate Office for Peasant Affairs, composed of a permanent member as chairman and two district commissioners appointed on a rotation basis ${ }^{15}$.

As regards the above-mentioned responsibilities, the Governorate Offices for Peasant Affairs performed both functions appropriate for an administrative body deciding at first instance in matters reserved for its jurisdiction (items 1-2, 4-5, and 10-11), and supervisory functions towards activity of administrative bodies reporting to them, i.e. district commissioners (items $6,8,9$ and 12), in which they acted as administrative bodies of second instance, interpretative functions (item 7), and judicial functions where these offices acted as administrative courts of first instance (items 3 and $\mathrm{a}-\mathrm{c}$ ).

13 Decree of 19 February / 2 March 1864 on the establishment of the organisational Committee in the Kingdom of Poland, "Journal of Laws", Vol. 62, pp. 149-151, Article 17 items a-j.

14 Decree of 18 / 30 November 1870 on the establishment, at the Ministry of Interior, of the Interim Commission for Peasant Affairs in governorates of the Kingdom of Poland, pp. 59-61, Article 1 items 2 a-d.

15 "For the matters referred to in items a-c, a separate office shall be established at the Governor's office, under the presidency of the permanent member and composed of at least two district commissioners, who shall be assigned for the meetings of this office according to the order laid down [...]" - Decree of 18 / 30 November 1870 on the establishment, at the Ministry of Interior, of the Interim Commission for Peasant Affairs in governorates of the Kingdom of Poland, p. 61, Article 1 item 2. 
Originally, all appeals against decisions of Governorate Offices for Peasant Affairs were brought by applicants to the Interim Commission for Peasant Affairs of Governorates of the Kingdom of Poland, established for this purpose at the Ministry of Interior in St. Petersburg ${ }^{16}$. In cases where the governorate offices decided in the second instance, the Commission adjudicated under the cassation procedure, while in other cases - under a mere appeal procedure. Rulings of the Commission could be challenged with a further appeal to the Minister of the Interior within three months of their announcement, while decisions of the Minister could be appealed against to the Committee for the Kingdom of Poland, which ultimately settled the case $^{17}$. After the liquidation of the Committee for the Kingdom of Poland in 1881, appeals submitted to it against the decisions of the Commission and the Minister of the Interior were transferred temporarily to the jurisdiction of the Main Committee for the Organisation of Peasantry. A year later, this Committee was dissolved and its responsibilities in contentious cases were taken over by the Department of Peasant Affairs at the $1^{\text {st }}$ Department of the Governing Senate, transformed into an independent $2^{\text {nd }}$ Department in 1884, also known as the "Department for Peasantry of the Governing Senate" (Krestyansky Departament Pravitelstvuyushchago Senata) ${ }^{18}$. In the same year, the Interim Commission for Peasant Affairs of Governorates of the Kingdom of Poland was renamed the "Office for Peasant Affairs of Governorates of the Kingdom of Poland" (Prisutstve po Krestyanskim Delom Guberniy Tsarstva Polskago), operating within the Land Department of Ministry of Interior (Zemskoe Otdeleniye Ministerstva Vnutrennykh Del $)^{19}$.

16 "For the management of peasantry affairs, the Ministry of Interior establishes a Temporary Peasant Affairs Commission for the Government of the Kingdom of Poland, consisting of the Chairman and two members appointed by the Supreme Authority upon request of the Minister of Interior" - Decree of 18 / 30 November 1870 on the establishment, at the Ministry of Interior, of the Interim Commission for Peasant Affairs in governorates of the Kingdom of Poland, p. 61, Article 1 item 3.

17 "Appeals against decisions of the Interim Commission for Peasant Affairs of Governorates of the Kingdom of Poland may be submitted to the Minister of Interior within 30 days of the Commission's decision being announced. As to appeals considered by the Minister unfounded, he communicates a negative decision to the interested parties; and if he finds that the appeal deserves to be upheld, and if the appeal has been lodged, also within 30 days, against the decision of the Minister himself, he shall present such a decision together with his opinion to the Committee for the Kingdom of Poland" - Decree of 18 / 30 November 1870 on the establishment, at the Ministry of Interior, of the Interim Commission for Peasant Affairs in governorates of the Kingdom of Poland, p. 63, Article 3. See also C. Ochryzko-Włodarska, op. cit., p. 31.

18 Decree of 25 May / 6 June 1882 on the liquidation of the Main Committee for the Organisation of Peasantry and appointment of the Department of Peasant Affairs at the Ministry of the Interior. Collection of Rights, "Provisions and Regulations of the Government in the Governorates of the Kingdom of Poland", Vol. 21, pp. 211-215; Decree of 24 January / 5 February 1884 on the organisation of the $2^{\text {nd }}$ Department of the Governing Senate, PSZRI 1884, No. 1978, pp. 124-132, Articles 1-20.

19 Decree of 28 February / 12 March 1884 on the liquidation of the Interim Commission for Peasant Affairs and on renaming it as the Office for Peasant Affairs of Governorates of the Kingdom 
As a result of these transformations there was a change in the scope of jurisdiction of the authorities to which appeals had been brought against the decisions of Governorate Offices for Peasant Affairs. Decisions taken by them at the first instance could be challenged, within 3 months of their announcement, to the Office for Peasant Affairs of governorates of the Kingdom of Poland at the Land Department of the Ministry of Interior, and then to the $2^{\text {nd }}$ Department of the Governing Senate, in the second instance - directly to the $2^{\text {nd }}$ Department ${ }^{20}$.

\section{GOVERNORATE OFFICES FOR MILITARY DUTY}

The Statute of Military Duty of 1874 entrusted the direct management of recruitment to District and Regional Military Duty Offices (Uyeznya i Okruzhnya po Voinskoy Povinnosti Prisutstviya). Their responsibilities were confined to purely administrative activities related to enlistment of recruits, such as making conscription lists and the carrying out of medical examinations ${ }^{21}$. On the other hand, the capacity of supervisory authority and, at the same time, appellate bodies for the decisions of those offices was exercised by the Governorate Offices for Military Duty ( $G u$ bernskiya po Voinskoy Povinnosti Prisutstviya). Their personal composition was characteristic of the Russian mixed offices. They were staffed by representatives of the ministries of interior, war and justice. They were always presided by the governor, and other members included: the deputy governor, the commander of military troops deployed in the governorate, the prosecutor of the regional court or his deputy (companion prosecutor) and a permanent member managing the proceedings at the office, appointed by the governor. Moreover, in interior governorates of the Empire with self-government bodies operating, this staff was supplemented by the governorate marshal of the gentry and the chairman and one of the members of the governorate land self-government ${ }^{22}$. In the Kingdom of Poland, as well as

of Poland, PSZRI 1884, No. 2058, pp. 538-541; Uchrezhdeniye Ministarstv, "Svod Zakonov" 1892, p. 52 , Article 384 .

${ }^{20}$ The responsibilities of the $2^{\text {nd }}$ Department of the Governing Senate shall cover: " $[\ldots]$ resolving, as the second instance, appeals on the activities of the governorate offices for peasant affairs in the Polish Kingdom, and appeals from decisions taken by the Land Department of the Ministry of Interior in contentious cases from governorates of the Kingdom of Poland resolved in the first instance in the Governorate Offices for Peasant Affair" - Uchrezhdeniye Pravitelstvuyushchago Senata, p. 7, Article 20 item 4. See also J.J. Litauer, O terminach i trybie podawania skarg w sprawach administracyjnych Królestwa Polskiego, Warszawa 1897, pp. 19-20.

21 The composition and detailed list of responsibilities of these offices were set out in Articles 102 and 103 of the Statute. See Ustav o voinskoy povinnosti, izdanije 1897, "Svod Zakonov" 1912, pp. 27-28.

22 "In every governorate and region there shall be a governorate or regional office for military conscription, presided by the Governor or the head of the region and composed of the following 
in the Baltic and Siberian governorates, deprived of self-government bodies at the governorate level, the place of the latter was occupied by: the permanent member of the Governorate Office for Peasant Affairs and one district commissioner for peasantry from the territory of the governorate ${ }^{23}$.

Responsibilities of the Governorate Offices for Military Duty covered as follows:

1. General supervision over conscription process, 2. Distribution of recruits between designated military units, 3. Re-examination of persons summoned for military service, 4. Recognition of appeals against district and regional offices for military duty, 5. Recognition of reports of local offices for military duty and preparing a general governorate report, and 6. Resolving legal doubts arising in local offices ${ }^{24}$.

Among them, supervisory functions include those listed in items 1, 3 and 6; the administrative - those listed in items 2 and 5, while the last, indicated in item 4, were of administrative and judicial nature.

As the authorities superior to the lower authorities of conscription administration, the Governorate Military Duty Offices performed the functions of instance supervision over them. This supervision took the form of managerial supervision, because under this mode of proceeding the Governorate Office was authorised not only to repeal decisions of district and regional offices whenever found a violation of the law or other "irregularity", but also by ordering a medical re-examination, to intervene directly in their decision-making proceeding ${ }^{25}$. However, the exercise of supervision in the event of doubts as to the scope of applicability of legal provisions by district and regional offices was more complex. Where such a situation had arisen before the decision was taken by the district or regional offices, the Governorate

members: governorate marshal of the gentry, chairman of the governorate land board, one member appointed by the board, the wartime governorate head or his deputy, and prosecutor of the regional court or his deputy" - ibidem, pp. 25-26, Article 99.

23 "In the Baltic governorates, governorates of the Kingdom of Poland and Siberian governorates, the following shall be appointed instead of the chairman and member of the land board: in the Baltic governorates - a separate member on behalf of the government and a member of the peasantry commission; in the governorates of the Kingdom of Poland - a permanent member of the governorate office for peasant affairs and one of the district commissioners for peasant affairs; in Siberian governorates - the councilor of the governorate or regional government" - ibidem, p. 26, Article 100 item 44.

${ }^{24}$ Ibidem, pp. 29-30, Article 107 items 1-6.

25 "The recruitment offices shall not be obliged to comply with the opinion of the examining physicians in respect of qualification of the recruits as fit or unfit for duty. The persons who are present at the examination shall be entitled to object against the recognition of a person as unfit for duty. These objections shall be lodged orally for the record at the district, regional or municipal office and the governorate office shall be entitled to order a further examination of even persons covered by an unanimous order of the office which has performed the examination" - ibidem, pp. 40-41, Article 149. 
office issued an order, which was an administrative act, in which it presented its own interpretation together with an instruction on the further conduct in the case. Where such doubts arose after the adoption of the decision, such an order had the nature of an administrative and judicial decision, repealing or amending the defective decision of district or regional authorities ${ }^{26}$. It should be noted that this right was vested in governorate offices only for a period of two years after the decision taken by regional and district offices ${ }^{27}$.

Concerning the administrative and judicial functions, those referred to in Article 107 item 4 of the general authorities merely spoke of appeals against local offices, without a clear definition of administrative activity subject to challenge in governorate offices. The only exception was the provision of Article 224, which provided for the possibility of lodging a complaint by a conscript on "institutions and officials arranging detailed conscription lists, as to their inaccuracies" ${ }^{\prime 28}$. Nevertheless, according to Article 228, all other decisions of district and regional offices could be challenged, via these offices, to governorate offices within four weeks of their issuance ${ }^{29}$.

In governorate office proceedings caused by lodging an appeal against the decisions of district and regional offices, the rules of procedure set out in the general organisation of the governorate were applied. Its execution was entrusted to the secretary and the governor's chancellery under the direct supervision of a permanent member appointed by the governor ${ }^{30}$. Rulings issued as a result of these proceedings took the form of a decision. Decisions of the governorate office regarding the preparation of the lists of conscripts and their eligibility for military service were final and were not subject to further appeal ${ }^{31}$. In other matters, the

26 S. Goriainov, Ustavy o voinskoy povinnosti, Sankt Peterburg 1908, p. 231; S.A. Korf, op. cit., Vol. 1, pp. 156-1.

27 "The activities and decisions of district offices can be reviewed and revoked by governorate offices for military duty independently of complaints from individuals if two years has elapsed since the act or the decision of the district office" - Ustavy o voinskoy..., pp. 29-30, remark on item 1 Article 107. See also J.J. Litauer, op. cit., pp. 11-12. In Russian literature, this limitation of the exercise of supervisory functions in respect of the activities of municipal and district offices was justified solely by political reasons, "Since the Ministry of Interior has always sought to protect the rulings of local authorities from the overly extensive interpretation of supervisory attributes by governorate authorities" - S.A. Korf, op. cit., Vol. 2, p. 156.

28 Ustavy o voinskoy..., p. 49, Article 224.

29 "Appeals against all other decisions of district, regional and municipal offices shall be submitted to the governorate office within four weeks from the date of announcement of the decision" - ibidem, p. 49, Article 228.

30 "Conducting cases in governorate and regional offices for military duty is entrusted to the secretary of the office and the governor's chancellery" - ibidem, p. 31, Article 110.

31 "Decisions of the governorate office in the following matters shall be deemed final and cannot be appealed: preparation of lists of conscripts, and determining the age according to one's external appearance" - ibidem, p. 49, Article 233. 
interested individual or members of his family had the right to lodge an appeal with the $1^{\text {st }}$ Department of the Governing Senate within two months from the date of the decision. For this purpose, the governorate office was obliged, without examining whether the appeal was grounded or not, to remit it to the Senate together with all the documents of the case ${ }^{32}$.

\section{GOVERNORATE OFFICES FOR FACTORIES AND MINING AFFAIRS}

The next "mixed offices", considered by Russian scholars of law as administrative courts of first instance, were governorate offices for factory and mining affairs (Gubernskiya po Fabrichnym i Gornozavodskim Delam Prisutstviye). They were established in 1899 as a result of the merger of the previously separate industrial inspectorate existing since 1886, and the mining inspectorate established in $1892^{33}$. In the system of administrative authorities of the Empire they were the lower link of the Industrial Inspectorate - a body of labour law administration, established in 1882 to supervise labour relations in factories and manufacturing plants of the Empire. Their composition and responsibilities were initially defined by the "Regulations on the supervision of industrial plants and mutual relations between factory owners and workers" of 1886, introduced in the Kingdom of Poland five years later, and the provisions of the "Statute on industry" of 1893, which were amended many times in later years ${ }^{34}$. According to their provisions, Governorate Offices for Factory and Mining Affairs were composed of "the Governor as the chairman, Deputy Governor, district court prosecutor, governorate head of gendar-

32 "In other matters, appeals about decisions of the governorate office shall be directed via the office to the $1^{\text {st }}$ Department of the Governing Senate within a two-month time limit" - ibidem, pp. 49-50, Article 234. See also: J.J. Litauer, op. cit., p. 21.

33 H. Altman, Ustawodawstwo fabryczne i inspekcja fabryczna, „Archeion” 1952, t. 21, pp. 5455; S.A. Korf, op. cit., Vol. 1, pp. 192-198; I.I. Szełymagin, Fabrichno-trudovoe zakonodatelstvo $v$ Rossii, Moskva 1947, p. 135.

34 Opinion of the Council of State of 3 / 15 June 1886 - Provisions on the supervision of industrial plants and mutual relationships between factory owners and workers, PSZRI 1886, No. 3769 , pp. 262-270, Articles 1-43; Opinion of the Council of State of 11 / 23 June 1891 on extending the law on employment in factories, manufacturing plants and craft production plants and the factory supervision to the governorates of the Kingdom of Poland, PSZRI 1891, No. 7817, pp. 388-389, Articles 1-6; Ustav o promyshlennosti, izdaniye 1893, "Svod Zakonov" 1912, pp. 1191-1250, Articles 1-488; Opinion of the Council of State of 14 / 26 March 1894 on the transformation of the industrial inspectorate and activities of governorate engineers, PSZRI 1894, No. 10420, pp. 106-109, Articles 1-20; Decree of 7 / 19 June 1899 on the General Office for Factory and Mining Affairs, PSZRI 1899, No. 17122, pp. 672-678, Articles 1-21; Order of the Committee of Ministers of 30 May / 12 June 1903 on the procedure for subordination of the industrial inspectorate to governors and on certain modifications in the internal organisation of industrial inspectorate, PSZRI 1903, No. 23041, pp. 560-561. 
merie, police head for Warsaw, district factory inspector, district mining engineer (after 1899) and two, and after 1899 four, representatives of local factory owners designated by the governor" 35 . The meetings of governorate offices could also be attended by "persons from whom useful information and explanations could be expected" acting in an advisory capacity ${ }^{36}$.

Responsibilities of Governorate Offices for Factory and Mining Affairs covered the following:

1. Issuing orders concerning means of protection of life and health in factories and industrial plants in the territory of the governorate, 2 . Resolving cases on infringement of rules and procedures of factory management, 3. Recognition of appeals against decisions of labour inspection officials and repealing their instructions, 4. Approving detailed rules concerning the situation of particular employee classes, 5 . Resolving doubts encountered by labour inspection officials during the application of factory regulations $\mathrm{s}^{37}$.

The functions set out in items 1 and 4 were of strictly administrative nature and boiled down to issuing by the governorate office an administrative act (decision or order) in the matters entrusted to its administrative jurisdiction and, as such, were subject to appeal to the authority that was superior over the governorate office, i.e. to the Chief Industrial Inspector, and since 1894 - to the Finance Minister in St. Petersburg. The supervisory function of governorate office was indicated in item 2. The settlement, mentioned therein, in cases concerning the violation of rules and the procedure of management in factories consisted in the assessment of on-going activity of industrial inspectors by the governorate office, not on the basis of appeals but rather as a result of the review of reports on their official activities. Under item 5, governorate offices had the power to interpret applicable labour provisions, which can be regarded as entrusting them with a function corresponding to the French concept of contentieux de l'interprétation, while the administrative and judicial functions, consisting in the governorate office conducting the proceedings in order to resolve a dispute, were set out in item 3.

General supervision over the proceedings in Governorate Offices for Factory and Mining Affairs was exercised by the regional industrial inspector, acting in

35 Opinion of the Council of State of 3 / 15 June 1886 - Provisions on the supervision of industrial plants and mutual relationships between factory owners and workers, p. 262, Article 2; Ustav o promyshlennosti..., p. 1195, Article 49; Decree of 7 / 19 June 1899 on the General Office for Factory and Mining Affairs, PSZRI 1899, No. 17122, p. 672, Article 3.

36 Opinion of the Council of State of 3 / 15 June 1886 - Provisions on the supervision of industrial plants and mutual relationships between factory owners and workers, p. 263, Artilce 3; Ustav o promyshlennosti..., p. 1196, Article 50.

37 Opinion of the Council of State of 3 / 15 June 1886 - Provisions on the supervision of industrial plants and mutual relationships between factory owners and workers, p. 264, Article 5 items 1-5; Ustav o promyshlennosti..., pp. 1197-1198, Article 52 items 1-5. 
this respect in close consultation with the governor. However, it was the latter's responsibility to decide whether the conduct of a given case would be entrusted to a separate clerk always affiliated with the governorate office or to clerks of governor's chancellery ${ }^{38}$. For governorates of the Kingdom of Poland, this meant that all such matters had to be dealt with in the governor's chancellery. The very course of proceedings in contentious cases at a governorate office was based initially on the principles set out in the Opinion of the Council of State of 3/15 June 1886, superseded in 1893 by the procedural provisions contained in the "Statute on industry". Pursuant to their provisions, the right to appeal against unlawful decisions of factory or mining inspectorate officials, together with a request to repeal them, was vested in any interested employee within one month from the date of the announcement of the decision ${ }^{39}$. The case was prepared in substantive terms by a clerk of the governorate office or a designated officer of the governor's chancellery, and then the case was presented at the board of the office, which was held without the applicant's participation, by the industrial inspector or mining inspector. The decision quorum of the Governorate Office for Factory and Mining Affairs was composed of three members, with the law requiring the presence of the governor and the factory inspector or mining inspector. Decisions were being adopted by a majority of votes, but in the event of their even distribution, the vote of the chairman, i.e. the governor, was decisive. If the appeal was upheld, the rulings of the governorate office could lead to the decision being annulled - if had been issued contrary the law, and in other situations - to modify $\mathrm{it}^{40}$. The decisions issued by Governorate Offices for Factory and Mining Affairs thus issued were subject to appeal within one month of their announcement to the Minister of Finance, who acted in such matters in consultation with the Minister of Interior. Decisions of these bodies acting as an appellate instance, were final ${ }^{41}$. Therefore, a further appeal to the Governing Senate was ruled out.

38 "The cases in governorate offices for industrial affairs shall be entrusted to a senior industrial inspector under the general supervision of the president of the office or a clerk appointed by him from among the official staff of the governor's chancellery" - Opinion of the Council of State of 3 / 15 June 1886 - Provisions on the supervision of industrial plants and mutual relationships between factory owners and workers, p. 265, Article 4. See also Ustav o promyshlennosti..., p. 1196, Article 51.

39 "Appeals against decisions of the industrial inspectorate officers shall be filed with governorate offices for industrial affairs within a month from the date of announcement of the decision" - Opinion of the Council of State of 3 / 15 June 1886 - Provisions on the supervision of industrial plants and mutual relationships between factory owners and workers, p. 268, Article 10. See also Ustav o promyshlennosti..., p. 1199, Article 57; J.J. Litauer, op. cit., p. 32.

40 Ustav o promyshlennosti..., p. 1199, Article 59-60.

41 "Decisions taken by governorate offices for industrial affairs may be appealed against, within a month, to the finance minister who shall issue the decision in consultation with the minister of interior. Such decisions shall be deemed final" - ibidem, p. 1198, Article 53. See also J.J. Litauer, op. cit., p. 33 . 


\section{GOVERNORATE OFFICES FOR INDUSTRIAL TAX}

The Decree of 8 / 20 June 1898 introduced, for the whole territory of the Empire, "Provisions on state industrial tax", which in 1903 was incorporated into the "Statute on direct taxes"42. Both of these acts entrusted the assessment and collection of this tax to revenue offices, which have only been authorised to administrative activities in this respect. At the same time, independently, Governorate Offices for Industrial Tax (Gubernskiya po Promyslovomu Nalogu Prisutstviya) were established as an appellate instance "to decide on appeals against decisions of revenue offices and their officials"43. As in the case of the other mixed offices, they were composed of:

[...] the Governor as chairman, the Deputy Governor, the head of revenue office and governorate office for excise duty, prosecutor at the Regional Court or his deputy, president of the governorate land self-government, mayor or president of the governorate capital city, or their deputies, and two members - payers of the industrial tax, elected for four years, each by the town council of the governorate capital city and the governorate land assembly ${ }^{44}$.

Furthermore, in matters concerning the imposition of penalties for infringements of the industrial tax rules, the president of the local regional court was being invited to the meeting of the board of the governorate office with a conclusive voice. In such an event, the payers of the industrial tax were excluded from the composition of that meeting ${ }^{45}$. In the Kingdom of Poland and other governorates of the Empire, which did not have any land and municipal self-government, the representatives of payers of the industrial tax were replaced by permanent members appointed by the governor out of the officials of governorate offices for peasant affairs and one of the councillors of the local governorate boards, and only in Warsaw this function was exercised ex officio by the head of the local police ${ }^{46}$.

42 Decree of 8 / 20 June 1898 - Provisions on the state industrial tax, PSZRI 1898, No. 15601, pp. 489-515, Articles 1-180; Ustav o priamykh nalogakh, izdaniye 1903, "Svod Zakonov" 1912, Vol. V, pp. 1-150, Articles 1-789.

43 "For hearing appeals against decisions of revenue offices on the subject of state industrial tax, governorate offices for industrial tax shall be established. If the district of the revenue office is not limited to one governorate, the governorate office indicated specified herein shall cover that district with its jurisdiction" - Decree of 8 / 20 June 1898 - Provisions on the state industrial tax, p. 495, Article 13. See also Ustav o priamykh..., pp. 48-49, Article 380.

44 Decree of 8 / 20 June 1898 - Provisions on the state industrial tax, p. 495, Article 14; Ustav o priamykh..., p. 49, Article 381 .

45 "When hearing cases of violation of the provisions on state industrial tax, a composition of the office shall be supplemented by the president of the local regional court or his deputy, with a decisive vote. In such cases, the prosecutor presents to the office only his conclusions as to the content of the ruling, but he does not take part in its issuance [...]" - Decree of 8 / 20 June 1898 - Provisions on the state industrial tax, pp. 495-496. See also Ustav o priamykh..., p. 49, Article 382.

46 "In governorates of the Kingdom of Poland, the representatives of land offices shall be replaced by permanent members of the local governorate offices for peasant affairs, and the representatives of 
Unlike other "mixed offices", Governorate Offices for Industrial Tax did not combine administrative functions with administrative and judicial powers. Their responsibilities covered the three categories of matters: 1 . Hearing the appeals against decisions of revenue offices in matters concerning the assessment and collection of the industrial tax, 2. Ruling at first instance on the annulment of decisions of revenue offices in matters concerning the amount of percentage-based levy on profits from industrial activity, challenged by their managers, and 3 . Hearing the appeals against decisions of revenue offices imposing a penalty for infringement of provisions on the industrial tax ${ }^{47}$. Appeals in such cases could be filed both by the industrial tax payers concerned and by heads of revenue offices, within one month from the announcement of the revenue office's decision, with the submission of the complaint automatically suspending execution of the contested decision ${ }^{48}$.

The proceedings in the governorate office were entrusted to the revenue office under the supervision of the head of the direct tax department, except for cases involving the imposition of penalties, which were carried out by a governor's chancellery official or an official of the governorate board, appointed by the Governor $^{49}$. Meetings of the office were convened by its chairman, i.e. the Governor, as required and at his discretion, with the quorum for decisions being, apart from the chairman, composed of two members of the office ${ }^{50}$. The proceedings were closed to the public. Only in cases concerning the imposition of penalties by the revenue office for infringement of the rules on the industrial tax, the interested party (in this

towns shall be replaced as follows: in Warsaw - by the assistant of the city mayor (the head of local police), in other governorate capital cities - one of the councillors of the local governorate boards, appointed by the governor" - Decree of 8 / 20 June 1898 - Provisions on the state industrial tax, p. 496, note 1 on Article 22. See also Ustav o priamykh..., p. 50, Article 390 note 1.

47 Decree of 8 / 20 June 1898 - Provisions on the state industrial tax, p. 495, 507, 511, 514, Articles 13, 111, 112, 145, 173; Ustav o priamykh..., p. 48, 60, 65, 67, Articles 380, 480, 481, 514, 542.

48 "Appeals against decisions of revenue offices are filed via these revenue offices to the governorate office for industrial tax within a month of the announcement of the decision. [...] Filing an appeal suspends the implementation of the contested decision" - Decree of 8 / 20 June 1898 - Provisions on the state industrial tax, p. 507, Article 112; Ustav o priamykh ..., p. 60, Article 481.

49 "The proceeding in governorate offices for industrial tax in cases of penalties for infringements of the state industrial tax regulations shall be entrusted to one of the officials of the chancellery of the Governor or the chancellery of the governorate board, appointed by the Governor, and in other cases the head of this department of the revenue office which deals with matters of the industrial tax" - Decree of 8 / 20 June 1898 - Provisions on the state industrial tax, p. 496, Article 16. See also Ustav o priamykh..., p. 49, Article 383.

50 "Meetings of the Governorate Office for the Industrial Tax shall be appointed by its Chairman where appropriate, and shall be entitled to adopt a decision if it involves not less than two members, other than the chairman, including at least one of the payers of an industrial tax" - Decree of 8 / 20 June 1898 - Provisions on the state industrial tax, p. 497, Article 29. See also Ustav o priamykh..., p. 51, Article 397. 
case referred to as the "accused") was allowed to participate in the proceedings, with the right to be heard, but his absence did not halt the proceedings ${ }^{51}$.

The settlement of the cases submitted to the Governorate Office for the Industrial Tax should have been made within one month from the date of filing the appeal ${ }^{52}$. It decisions were taken by a simple majority of the members present, but in the event of being equal the chairman's vote prevailed ${ }^{53}$. Decisions of the office could be protested against by the head of the revenue office or prosecutor within two weeks of being announced. In such a case, the case was transferred via the Minister of Finance to the $1^{\text {st }}$ Department of the Governing Senate, and the execution of the decision was suspended ${ }^{54}$. In other cases, the interested party had the right to file an appeal directly to the Senate within one month from the service of the decision, but its filing did not suspend the execution of the decision of the office ${ }^{55}$.

\section{GOVERNORATE OFFICES FOR THE HOUSE RENTAL TAX}

In 1893, pursuant to the decree of 14 / 26 May, a uniform state tax on house rental was introduced in the Kingdom of Poland and the European governorates of the Empire, imposed on apartments rented out in urban multi-family houses ${ }^{56}$. The

51 "The date of the meeting of the office shall be notified to the accused and the right to participate in the case presentation and to be heard orally or in writing is dependent on the acceptance of this date; the accused's or his representative's failure to attend does not prevent the issuance of a decision" - Decree of 8 / 20 June 1898 - Provisions on the state industrial tax, p. 514, Article 174. See also Ustav o priamykh..., p. 67, Article 543.

52 "Appeals against decisions of revenue offices [...] should be heard within one month from their submission or supplementing [...]" - Decree of 8 / 20 June 1898 - Provisions on the state industrial tax, p. 507, Article 112. See also Ustav o priamykh ..., p. 60, Article 481.

53 "Cases dealt with in all governorate industrial tax offices shall be settled by a simple majority of votes. In the event of a tied vote, the Chairman shall have the casting vote" - Decree of 8 / 20 June 1898 - Provisions on the state industrial tax, p. 497, Article 31. See also Ustav o priamykh..., p. 51, Article 399.

54 "Decisions of the Governorate Office for the Industrial Tax which have been protested within two weeks by the head of the revenue office or the prosecutor of the regional court shall be suspended in execution, and within the same period of two weeks shall be remitted, through the Minister of Finance, to the Governing Senate (1st Department) to be decided" - Decree of 8 / 20 June 1898 - Provisions on the state industrial tax, p. 514, Article 176. See also Ustav o priamykh..., pp. 66-67, Article 545.

55 "Appeals against decisions of governorate offices for the industrial tax shall be submitted to the Governing Senate ( $1^{\text {st }}$ Department) within one month of the date on which a copy of the decision was served, and shall be submitted to the Senate together with explanations from the governorate office. [...] Filing an appeal does not suspend the execution of the contested decision" - Decree of $8 / 20$ June 1898 - Provisions on the state industrial tax, p. 514, Article 175. See also Ustav o priamykh..., p. 67 , Article 544 .

56 Decree of 14 / 26 May 1893 - Provisions on the state house rental tax, PSZRI 1893, No. 9612 , pp. 280-284, Articles 1-47. These provisions were integrated into the Statute on direct taxes in 1903. See Ustav o priamykh..., pp. 87-94, Articles 743-789. 
administration of this tax was entrusted, under the general supervision of revenue offices, to municipal offices for the house rental tax, operating at the municipalities of governorate capital cities and district towns. At the same time, the Governorate Offices for the House Rental Tax (Gubernskiya po Kvartirnomu Nalogu Prisutstviya) were established at individual revenue offices as an instance of appeal from municipal offices in matters related to the measurement and collection of this tax ${ }^{57}$. These offices were composed of: "heads of revenue offices as chairmen, heads of departments of revenue offices, constituting its board, heads of governorate capital cities, and two persons - taxpayers of the house rental tax, elected for three years by the town council or town board of the governorate capital city" ${ }^{158}$. In the Kingdom of Poland, where municipal self-government bodies were not introduced, the governorate offices were composed of: mayors of governorate capital cities and two payers of house rental tax appointed by them. In addition, when considering cases concerning district towns, the heads of these cities, i.e. mayors, had the right to sit in that office as members with a decisive voice ${ }^{59}$.

Responsibilities of Governorate Offices for House Rental Tax have been set out in Articles 23, 33 and 45 of the decree of 14 / 24 May 1893, which corresponded to the provisions of Articles 765, 775 and 787 of the "Statute on direct taxes" in the 1903 edition. These included: 1 . Re-examination of cases settled by a non-final decision of the municipal office at the request of its chairman, 2. Hearing the appeals from taxpayers against decisions of municipal housing offices, and 3. Processing of applications for deferment of payment of the tax charge or payment of it in instalments ${ }^{60}$.

The first case was a consequence of the fact that the heads of municipal offices were granted the right to refuse their approval for decisions taken by a majority of the members of the office board, but the regulations did not specify the content of such a protest, indicating only that the execution of the contested decision is suspended in such situations. The head of the municipal office could file such a protest within three days from the date of signing the minutes of the meeting of the municipal office ${ }^{61}$. Therefore, depending on the content of the protest of the

57 "General administration of the state house rental tax shall be entrusted to the local revenue office and governorate offices for the house rental tax established therein" - Decree of 14 / 26 May 1893 - Provisions on the state house rental tax, p. 282, Article 15. See also Ustav o priamykh..., p. 89, Article. 757.

58 Decree of 14 / 26 May 1893 - Provisions on the state house rental tax, p. 282, Article 16. See also Ustav o priamykh..., p. 89, Article 758.

59 Decree of 14 / 26 May 1893 - Provisions on the state house rental tax, p. 282, Article 16. See also Ustav o priamykh..., pp. 89-90, notes 1 and 2 on Article 758.

60 Decree of 14 / 26 May 1893 - Provisions on the state house rental tax, pp. 282-284, Articles 23, 33, 45. See also Ustav o priamykh..., pp. 90-92, Articles 765, 775, 787.

${ }^{61}$ "Decisions of the municipal office with which its head does not agree shall be suspended and the case shall be remitted within three days of the signature of the minutes of the Office's meetings for 
head of the municipal office, the governorate office acted either as an administrative body of a higher instance reviewing the legality of the decision issued by the municipal office, or as a judicial body of the first instance deciding on the merits of the municipal office's decision. In the second case, the governorate office acted precisely as a judicial body, hearing in the first instance appeals against decisions of municipal offices concerning the assessment of the house rental tax. Payers of this tax were entitled to appeal against such decisions within two weeks from the announcement of the decision ${ }^{62}$. However, the substantive scope of the appeal in such cases was limited by the law only to "an erroneous calculation of the amount of tax charged which had not been taken into account by the municipal office" 63 . Thus, the limits of recognition of the governorate office in such situations were limited to purely technical matters. On the other hand, the hearing by the municipal authorities of applications for deferred payment of the tax charge or its payment in instalments was not an administrative dispute (there is no appeal but only an application (khodataystivye) of the taxpayer), and boiled down to the issuance of a new administrative decision, independent of the municipal authority's decision on the amount of the tax ${ }^{64}$.

Appeals and applications to the Governorate Office for the House Rental Tax were filed via the municipal office. The conduct of preparatory and office activities was entrusted to the chancellery of the revenue office having jurisdiction over the location of the estate. Meetings of governorate offices were convened by its chairman "as needed" 65 . The quorum entitling to make a valid decision was at least three members of the office's board, including the chairman as a mandatory

settlement to the governorate office for the house rental tax" - Decree of 14 / 26 May 1893 - Provisions on the state house rental tax, p. 283, Article 23. See also Ustav o priamykh..., p. 90, Article 765.

62 "Decisions of the municipal office for the house rental tax which fail to consider the taxpayer's requests may be challenged, through this office, to the governorate office for the house rental tax within two weeks of the announcement of the decision" - Decree of 14 / 26 May 1893 - Provisions on the state house rental tax, p. 283, Article 33. See also Ustav o priamykh..., p. 91, Article 775.

63 "Payers of the house rental tax shall be entitled to submit to the governorate office, by 7 April of each year, objections against the erroneous calculation of the amount of tax levied" - Decree of 14 / 26 May 1893 - Provisions on the state house rental tax, p. 283, Article 32. See also Ustav o priamykh..., p. 91, Article 774.

64 "The governorate office for the house rental tax shall have the right to process the applications and requests of a taxpayer for deferment or dividing into instalments of the tax due to a burdensome family situation or other difficulties, in particular such as serious illness, loss of property or source of income and the like" - Decree of 14 / 26 May 1893 - Provisions on the state house rental tax, p. 284, Article 45. See also Ustav o priamykh..., p. 92, Article 787.

${ }_{65}$ Meetings of the governorate office for the house rental tax shall be convened by its chairman as necessary. Members of the office should be notified in writing on each meeting of the office" Decree of 14 / 26 May 1893 - Provisions on the state house rental tax, p. 282, Article 19. See also Ustav o priamykh..., p. 90, Article 761. 
participant and one member from outside the revenue office ${ }^{66}$. The proceedings were of a nature of internal administrative proceeding and took place without the participation of the applicant. It was based on the case report, developed essentially in the chancellery of the revenue office. Decisions of the office were made by a simple majority of votes, however, in the event of a tied vote, the chairman's vote prevailed. These decisions may be appealed against by interested parties to the Minister of Finance, via the governorate office, within one month from the day the decision was announced ${ }^{67}$. The lodging of the appeal did not suspend the execution of the decision ${ }^{68}$.

\section{GOVERNORATE OFFICES FOR ASSOCIATIONS}

The Nicholas II's Manifesto on the Improvement of the State Order of 17 / 30 October 1905, the so-called "October Manifesto", declared limited freedom of association and assembly for citizens of the Empire ${ }^{69}$. As a result, this right was included in the last edition of Fundamental Laws of the Russian Empire of $1906^{70}$. As an implementation of these provisions, two imperial decrees of $4 / 17$ March 1906 were issued: The "Provisional Law on Associations and Unions" and the "Provisional Law on Assemblies", which, symptomatically, were included in

66 "A meeting of the office shall be deemed to have been properly carried out if it has been attended by no less than three members, including the chairman. In order to deem the meeting of the office to be correct, it is necessary to have at least one member who does not belong to the tax chamber" - Decree of 14 / 26 May 1893 - Provisions on the state house rental tax, p. 282, Article 20. See also Ustav o priamykh..., p. 90, Article 762.

67 "Appeals against decisions of governorate office for the house rental tax are submitted to the minister of finance within one month from the date of the announcement of the decision" - Decree of 14 / 26 May 1893 - Provisions on the state house rental tax, p. 283, Article 34. See also Ustav o priamykh..., p. 91, Article 776.

68 "Filing an appeal against an incorrect charging of the tax or improper calculation of its amount shall not suspend tax collection" - Decree of 14 / 26 May 1893 - Provisions on the state house rental tax, p. 284, Article 36. See also Ustav o priamykh ..., p. 91, Article 778.

69 "We require the government dutifully to execute our unshakeable will to grant to the population the essential foundations of civil freedom, based on the principles of genuine inviolability of the person, freedom of conscience, speech, assembly and association" - Nicholas II's Manifesto of 17 / 30 October 1905 on the Improvement of the State Order, PSZRI 1905, No. 26803, p. 754 (English translation by D. Field, http://academic.shu.edu/russianhistory/index.php/Manifesto_of_October_17th, 1905 [access: 28.03.2019]).

$\overline{70}$ "Russian Subjects have the right to establish associations and unions provided that their objectives are not contrary to applicable law. The conditions for the establishment of associations and unions, their mode of action and the conditions and procedures for granting them legal personality and their liquidation shall be governed by separate regulations" - Svod Osnovnykh Gosudarstvennykh Zakonov, izdaniye 1906, "Svod Zakonov" 1912, p. 6, Article 80. 
Vol. XIV of the Collection of Laws among the provisions on crime prevention and counteraction $^{71}$.

These provisions distinguished between three types of associations: "1. Those having legal personality, 2 . Those not having legal personality (so-called ordinary associations) and 3. Trade unions" ${ }^{\text {"72 }}$. Formally speaking, all these institutions could be established without the official permission of administrative authorities if their by-laws met the requirements set out in the decree ${ }^{73}$. In fact, the establishment and operation of such associations and unions was subject to strict police control by the administrative authorities, which, acting within their discretion, could refuse to register them or could dissolve them if "they pursued objectives contrary to the law, to public morals, prohibited by criminal law" or where they "posed a threat to public peace and security" 74 .

The bodies appointed to supervise and review the establishment and activities of associations and unions were, following the example of Governorate Offices for Land and Municipal Affairs, the Governorate Offices for Associations (Gubiernskiya po Delam obshchestvakch Prisutstviya). They consisted of: the governor as chairman, deputy governor, head of the revenue office, prosecutor of the regional court, and one representative of each of the land, municipal and gentry self-government of the governorate ${ }^{75}$. In governorates of the Kingdom of Poland, deprived of municipal and land self-government, these representatives were replaced by three presidents of municipal courts appointed by the governor general ${ }^{76}$.

Responsibilities of Governorate Offices for Associations have been defined very generally as "the management of matters concerning the establishment, registration, prohibition and liquidation of associations and unions" "77. In fact, those offices operated either as an appellate instance against governor's decisions to

71 Decree of 4 / 14 March 1906 - Provisional law on associations and unions, PSZRI 1906, No. 27479, pp. 201-207, part I, Articles 1-40, part II, Articles 1-24; Decree of 4 / 14 March 1906 - Provisional law on assemblies, PSZRI 1906, No. 27480, pp. 207-209, Articles 1-21; Ustav o preduprezhdeniy i presecheniy prestupleniy, izdaniye 1890, "Svod Zakonov” 1912, Vol. XIV, pp. 131-136, Appendix to Article 151 item 1.

72 Decree of 4 / 17 March 1906 - Provisional law on associations and unions, p. 201, Article 1.

73 "Associations and unions may be established without seeking a permission from the authorities, provided that the provisions of the decree are respected" - ibidem, p. 201, Article 2.

74 Ibidem, p. 204, Article 33.

75 "For the management of matters concerning the establishment, registration, prohibition and liquidation of associations and unions, governorate offices for associations shall be established under the rules laid down for governorate offices for land and municipal matters"-ibidem, p. 202, Article 13.

76 "In governorates of the Kingdom of Poland, the governorate offices for associations shall be composed, under the leadership of the governor, deputy governor, head of the revenue office, prosecutor of the regional court, and three presidents of municipal courts of the governorate, elected by the governor general" - ibidem, p. 202, Article 14.

77 Ibidem, p. 202, Article 13. 
refuse, suspend or liquidate an ordinary association, or as a registration body for associations and unions with legal personality. In the first case, the founders informed the local governor of this, while submitting to him the assumptions and objectives of the association's activities. The governor's failure to respond to this notification within two weeks authorised the association to commence the activity. Where the governor did not intend to give his consent to the establishment of the association, he submitted the case for settlement to the Governorate Office for Associations ${ }^{78}$. The decision of the office to refuse registration of the association could be challenged by the founders to the $1^{\text {st }}$ Department of the Governing Senate within two weeks of issuance of the decision ${ }^{79}$. The same right was vested in the Minister of Interior at the request of the governor against the decision of the office authorising the registration of the association regardless his negative opinion ${ }^{80}$. However, in cases of associations seeking legal personality, the governorate office acted as a registration body. In such situations, once the opinion was expressed by the governor, the office carried out the registration procedure and was obliged to issue, within one month, a decision to register the association or union or to refuse its registration. In the first case, the statutes of the association were entered in the register of associations and unions, with the simultaneous publication of its text in the Senate's promulgation journal ${ }^{81}$. In the event of refusal of registration or registration contrary to the governor's negative opinion, the founders of the association and the Minister of Interior had the right to appeal to the $1^{\text {st }}$ Department of the Senate within two weeks of the decision ${ }^{82}$. Similar rules of procedure related to the suspension or liquidation of an association or a union, with the initiative to do so being reserved for the governors (in the Kingdom of Poland, the governor general)

78 "Persons wishing to set up an association are obliged to notify the governor, who, in the case of finding an obstacle preventing the establishment of the association, shall notify the governorate office for associations and remit the case to it for settlement. If the Governor's opinion is not referred to the office for settlement within two weeks, the association may start its activity" - ibidem, p. 202, Article 17.

79 "Decisions of the governorate office for associations may be challenged by interested parties within two weeks of the decision being issued, to the $1^{\text {st }}$ Department of the Governing Senate, via governors, along with the grounds for the decision" - ibidem, p. 204, Article 38.

80 "Governors shall have the right to suspend the execution of the decision of the governorate office for associations, by a majority vote, and refer the case to the minister of interior, who either orders the governor to execute the decision or applies to the Governing Senate to revoke or change it"-ibidem, p. 204, Article 39.

81 "The draft by-laws of an association subject to registration shall be submitted to the governorate office for associations via and at the request of the governor. The Office is obliged to examine the draft within one month. The office shall order or refuse the registration. In the first case, the registration takes place by entering the association into a register kept by that office"; "The office shall notify of the registration the editorial board of the Senate News, along with the text of its by-laws" - ibidem, p. 203, Article 39.

82 Ibidem, p. 204, Articles 38-39. 
who, whenever found the activity of the association or union as "posing a threat to the public security and peace, or going in a completely immoral direction", were authorised to suspend their activities and apply directly to their management boards with a request for the voluntary dissolution of the association and, if they are refused, refer the case to the Governorate Office for Associations and then to the Minister of Interior ${ }^{83}$.

Looking at the Governorate Offices for Associations, it should be noted that despite the freedom of establishing and operating associations and unions declared after 1905, in reality they were established in order to exercise police and administrative supervision and control over this sphere of rights and freedoms of the population of the Russian Empire. This is manifested both by entrusting them to the governors, the predominance of the bureaucratic element in their staffing, as well as the concentration of preparatory activities and proceedings in such matters in the hands of governor's chancelleries and governorate boards ${ }^{84}$. Moreover, in the association/union registration procedure, their founders did not act as a party, but only as its participants, with the right to submit explanations at the request of the chairman ${ }^{85}$. Consequently, it should be noted that the functions of these offices were closer to supervisory functions carried out in the course of the instances of intra-administrative proceedings, rather than tasks characteristic of an autonomous administrative judicial body ${ }^{86}$.

\section{CONCLUSIONS}

Following the unification activities undertaken by the tsarist authorities in the Kingdom of Poland after the January Uprising, all autonomous organs of the central government were liquidated, and the territorial administration of the Kingdom was adapted to the models existing in the Russian Empire. As a result of these changes, the supervisory functions were taken over by the newly established bodies of the governorate and district administration of individual sectors of ministerial admin-

83 Ibidem, p. 204, Articles 33-35.

84 "The proceedings in governorate offices for associations shall be entrusted, according to a decision of the governor, to his chancellery or the chancellery of the governorate board [...]"-ibidem, p. 202, Article 15 .

85 "At the governor's request, the persons concerned may be heard before the case is settled" - ibidem, p. 204, Article 36.

${ }^{86}$ As S.A. Korf (op. cit., Vol. 2, p. 250) put it, without hiding his disappointment: “[...] regretfully, it should be noted that in this case the legislature did not recognise the existence of subjective public rights of Russian citizens, therefore, the legal structure of responsibilities of those offices in the area of administrative judiciary raises many doubts, becoming more like of an advisory body at the governor, issuing decisions that are not so much administrative-judicial decisions, but purely administrative acts". 
istration, for which the ministers residing in St. Petersburg were the final decisive body. On the other hand, the abolition of the Council of State of the Kingdom of Poland in 1867 entailed the final liquidation of the administrative justice system based on the French model, which had operated on these lands since the times of the Duchy of Warsaw. Instead, the Russian system of public administration control was introduced, fundamentally deviating from the principles of judicial control of administrative decisions that were already widely accepted in contemporary European countries. It only provided for the option of appealing against the administrative decisions listed by the legislature before specially established bodies, i.e. the so-called "mixed offices". Unlike administrative courts, these offices formed an integral part of the governorate administration, and their clerical staff as well as the bureaucratic method of operation compromised their judicial independence. Moreover, the procedure for dispute resolution in these offices had the character of an intra-administrative procedure which did not employ the concept of a party, and its discretionary course excluded the possibility of applying the principles of adversarial process, openness to the public or dispositiveness. Out of all the "mixed offices" operating in the Russian administration, the administration in the Kingdom of Poland lacked the Governorate Offices for Municipal and Land Affairs, as the tsarist authorities had not established self-government institutions of this level in the Kingdom. Moreover, the peculiarity of "mixed offices" in the Kingdom of Poland, resulting solely from political reasons, was the reduction of their staffing only to the bureaucratic element and full subordination of their substantive and formal side of the proceedings to the governorate authorities. As a result, the judicial activity of "mixed offices" in administrative matters in the Kingdom of Poland was much more dependent on the current policies of the tsarist authorities represented and supervised directly by the governors than in the interior governorates of the Empire. The combination of these factors with the discretionary rules of intra-ministerial proceedings applied in these offices deprived inhabitants of the Kingdom of Poland of a guarantee of impartial defence of their rights and interests in disputes with the administration that was foreign and distrustful to them. Therefore, one of the consequences of the reorganisation of public administration in the Kingdom of Poland after the January Uprising was the liquidation of the administrative judiciary existing in those lands for half a century and replacing it with a quasi-judicial review of administration carried out on the local ground by the so-called "mixed offices", which due to their specificity only partially filled the gap, constituting a clear step back as compared with previous, classic solutions functioning in this respect in the Kingdom of Poland. 


\section{REFERENCES}

Altman H., Ustawodawstwo fabryczne i inspekcja fabryczna, „Archeion” 1952, t. 21.

Boć J., Kontrola prawna administracji, [in:] Prawo administracyjne, red. J. Boć, Wrocław 1997.

Decree of 2 / 13 March 1711 on the authority and responsibility of the Governing Senate, "Polnoe Sobraniye Zakonov Rossiyskoy Imperii” 1830, No. 2328.

Decree of 19 February / 2 March 1861 - Provisions on the organisation of governorate and district offices for peasant affairs, "Polnoe Sobraniye Zakonov Rossiyskoy Imperii” 1861, No. 36660.

Decree of 19 February / 2 March 1864 on the establishment of the organisational Committee in the Kingdom of Poland, "Journal of Laws", Vol. 62.

Decree of 18 / 30 November 1870 on the establishment at the Ministry of Internal Affairs of the Interim Commission for Peasant Affairs in the Governorates of the Kingdom of Poland and renaming the Peasantry Commissions in the Kingdom of Poland into governorate offices for peasant affairs, "Journal of Laws", Vol. 71.

Decree of 25 May / 6 June 1882 on the liquidation of the Main Committee for the Organisation of Peasantry and appointment of the Department of Peasant Affairs at the Ministry of the Interior. Collection of Rights, "Provisions and Regulations of the Government in the Governorates of the Kingdom of Poland", Vol. 21.

Decree of 24 January / 5 February 1884 on the organisation of the $2^{\text {nd }}$ Department of the Governing Senate, "Polnoe Sobraniye Zakonov Rossiyskoy Imperii” 1884, No. 1978.

Decree of 28 February / 12 March 1884 on the liquidation of the Interim Commission for Peasant Affairs and on renaming it as the Office for Peasant Affairs of Governorates of the Kingdom of Poland, "Polnoe Sobraniye Zakonov Rossiyskoy Imperii" 1884, No. 2058.

Decree of 14 / 26 May 1893 - Provisions on the state house rental tax, "Polnoe Sobraniye Zakonov Rossiyskoy Imperii" 1893, No. 9612.

Decree of 8 / 20 June 1898 - Provisions on the state industrial tax, "Polnoe Sobraniye Zakonov Rossiyskoy Imperii” 1898, No. 15601.

Decree of 7 / 19 June 1899 on the General Office for Factory and Mining Affairs, "Polnoe Sobraniye Zakonov Rossiyskoy Imperii" 1899, No. 17122.

Decree of 4 / 14 March 1906 - Provisional law on assemblies, "Polnoe Sobraniye Zakonov Rossiyskoy Imperii" 1906, No. 27480.

Decree of 4 / 14 March 1906 - Provisional law on associations and unions, "Polnoe Sobraniye Zakonov Rossiyskoy Imperii” 1906, No. 27479.

Duniewska Z., Jaworska-Dębska B., Michalska-Badziak R., Olejniczak-Szałowska E., Stahl M., Prawo administracyjne. Pojęcia, instytucje, zasady w teorii i orzecznictwie, Warszawa 2000.

Elistratov A.I., Osnovnye nachala administrativnogo prava, Moskva 1914.

Goriainov S., Ustavy o voinskoy povinnosti, Sankt Peterburg 1908.

Grzybowski K., Historia państwa i prawa Polski, t. 4: Od uwłaszczenia do odrodzenia Państwa, Warszawa 1982.

Ivanowsky V.V., Uchebnik administrativnogo prava, Kazan 1908.

Izdebski H., Historia administracji, Warszawa 1997.

Korf S.A., Administratiwnaja justicja w Rossiji, Vol. 1-2, Sankt Peterburg 1910.

Korkunov N.M., Russkoe gosudarstvennoe pravo, Vol. 2, Sankt Peterburg 1908.

Litauer J.J., O terminach i trybie podawania skarg w sprawach administracyjnych Królestwa Polskiego, Warszawa 1897.

Nicholas II's Manifesto of 17 / 30 October 1905 on the Improvement of the State Order, "Polnoe Sobraniye Zakonov Rossiyskoy Imperii” 1905, No. 26803 (English translation by D. Field, http://academic.shu.edu/russianhistory/index.php/Manifesto_of_October_17th, 1905 [access: 28.03.2019]). 
Mogilnicki A., Sąy administracyjne, Warszawa 1900.

Ochendowski J., Prawo administracyjne. Część ogólna, Torun 2006.

Ochryzko-Włodarska C., Organizacja władz włościańskich w Królestwie Polskim i ich pozostałość aktowa, Warszawa 1973.

Opinion of the Council of State of 3 / 15 June 1886 - Provisions on the supervision of industrial plants and mutual relationships between factory owners and workers, "Polnoe Sobraniye Zakonov Rossiyskoy Imperii" 1886, No. 3769.

Opinion of the Council of State of 11 / 23 June 1891 on extending the law on employment in factories, manufacturing plants and craft production plants and the factory supervision to the governorates of the Kingdom of Poland, "Polnoe Sobraniye Zakonov Rossiyskoy Imperii" 1891, No. 7817.

Opinion of the Council of State of 14 / 26 March 1894 on the transformation of the industrial inspectorate and activities of governorate engineers, "Polnoe Sobraniye Zakonov Rossiyskoy Imperii" 1894, No. 10420.

Order of the Committee of Ministers of 30 May / 12 June 1903 on the procedure for subordination of the industrial inspectorate to governors and on certain modifications in the internal organisation of industrial inspectorate, "Polnoe Sobraniye Zakonov Rossiyskoy Imperii" 1903, No. 23041.

Prawo administracyjne, red. M. Wierzbowski, Warszawa 2000.

Starościak J., Prawo administracyjne, Warszawa 1978.

Svod Osnovnykh Gosudarstvennykh Zakonov, izdaniye 1906, "Svod Zakonov” 1912.

Svod Osnovnykh Gosudarstvennykh Zakonov Rossiyskoy Imperii, izdaniye 1835, "Svod Zakonov Rossiyskoy Imperii” 1835, Vol. I, part I.

Szełymagin I.I., Fabrichno-trudovoe zakonodatelstvo v Rossii, Moskva 1947.

Tarasov I.T., Kratky ocherk nauki administrativnogo prava, "Vriemennik Demidovskogo Juridicheskogo Litseya", Yaroslavl 1888.

Uchrezhdeniye Ministarstv, "Svod Zakonov Rossiyskoy Imperii” 1892.

Uchrezhdeniye Pravitelstvuyushchago Senata, "Svod Zakonov Rossiyskoy Imperii" 1892, Vol. I, part II, book IV.

Ustav o preduprezhdeniy i presecheniy prestupleniy, izdaniye 1890, "Svod Zakonov Rossiyskoy Imperii” 1912, Vol. XIV.

Ustav o priamykh nalogakh, izdaniye 1903, "Svod Zakonov Rossiyskoy Imperii” 1912, Vol. V.

Ustav o promyshlennosti, izdaniye 1893, "Svod Zakonov Rossiyskoy Imperii” 1912.

Ustav o voinskoy povinnosti, izdanije 1897, "Svod Zakonov Rossiyskoy Imperii” 1912.

Witkowski W., Historia administracji w Polsce 1764-1989, Warszawa 2007.

\section{STRESZCZENIE}

Rosyjski model nadzoru i kontroli administracji został wprowadzony w Królestwie Polskim równocześnie z reorganizacją zarządu gubernialnego i powiatowego po powstaniu styczniowym. Funkcje nadzorcze przejęły nowo utworzone organy administracji gubernialnej i powiatowej poszczególnych pionów resortowych, dla których ostateczną instancją decydującą byli ministrowie rezydujący w Petersburgu. Natomiast zniesienie Rady Stanu Królestwa Polskiego w 1867 r. oznaczało ostateczną likwidację sądownictwa administracyjnego opartego na modelu francuskim, istniejącego na tych ziemiach od czasów Księstwa Warszawskiego. Jego zadania przejęły tzw. urzędy mieszane, wypełniając jedynie częściowo powstałą lukę. W odróżnieniu od sądów administracyjnych urzędy te stanowiły integralną część administracji gubernialnej, a ich urzędniczy skład osobowy oraz biurokratyczny sposób funkcjonowania wykluczał ich niezależność orzeczniczą. Ponadto tryb postępowania w przypadku rozstrzygania kwestii spornych w tych urzędach miał charakter postępowania wewnątrzadministracyjnego, które nie znało pojęcia strony, a jego dyskrecjonalny przebieg wyklu- 
The Position and Role of So-called "Mixed Offices" in the Governorate Administration... 159

czał możliwość stosowania zasady kontradyktoryjności, jawności czy dyspozytywności. Specyfiką „urzędów mieszanych” w Królestwie Polskim, wynikającą wyłącznie z powodów politycznych, było ograniczenie ich składu personalnego jedynie do elementu biurokratycznego oraz pełne podporządkowanie merytorycznej i formalnej strony postępowania ich kolegiów decyzyjnych kontroli władz gubernialnych. W rezultacie działalność orzecznicza „urzędów mieszanych” w sprawach administracyjnych w Królestwie Polskim była zależna w zdecydowanie większym stopniu od aktualnych kierunków polityki władz carskich reprezentowanych i nadzorowanych bezpośrednio przez gubernatorów niż w wewnętrznych guberniach Cesarstwa. Połączenie tych czynników z dyskrecjonalnymi regułami postępowania wewnątrzadministracyjnego, stosowanymi w tych urzędach, pozbawiało mieszkańców Królestwa Polskiego gwarancji bezstronnej obrony ich praw i interesów w sporach z obcą i z założenia nieufną wobec nich administracją.

Słowa kluczowe: administracja; sądownictwo administracyjne; Królestwo Polskie; Cesarstwo Rosyjskie 